\title{
Camera Adventures with the American Bittern
}

\author{
By Doug Gilroy
}

Winter is by no means an unpleasant time of the year, but when the cold winds start to blow and send the snow swirling around the farm buildings, I like to sit by the warm fire and let my mind go back to the pleasant days of past summers. Many happy hours were spent then, endeavouring to photograph the wild things of nature. Thinking back I recall one summer's experience I had with a bittern.

By the way, did you ever hear the lovely love song of a bittern on a quiet spring evening? It is one of the strangest and most fascinating of bird calls.

Bitterns are members of the heron family and a dweller of the marshes, so naturally one has to be in suitable territory to hear them. The song is hard to describe. Sometimes it sounds rather like someone tapping a stick, followed by a throaty liquid yodel; other times it varies with other odd notes thrown in. On a quiet evening it will carry a long way and the distance seems to give it an added charm, so that one always stops and listens to hear it again. It must be heard to be appreciated.

One of these fellows had been singing his evening serenade for about two weeks straight, when I took up my camera and decided to try for some Bittern portraits to add to my collection of nature pictures. Surely after being on the air for more than two weeks he would have acquired a "Mrs." and a nest would be underway.

His territory proved to be a little marsh about $125 \mathrm{y}$ ards long and $25 \mathrm{y}$ ards wide. The water in the deepest part would be two feet deep. A heavy growth of dried rushes and coarse green grass hid the water al most completely from view. He wasn't the only bird that chose to make his home there. As I began to wade into the green and gold vegetation the cackle of rails greeted me. Redwing Blackbirds were singing, screaming and flying in all directions. Many of their nests were soon found; some not quite finished, others contained eggs.
Penetrating deeper I flushed a Canvas-back Duck from her nest of twelve greenish tan eggs. In another spot, where water was shallow and the cattails dense and dry, out flew a Marsh Hawk. She had been brooding four white ( with bluish cast) eggs, laid on a mat of dry grasses.

More searching revealed nothing but a Mallard's nest and more Blackbirds I was beginning to give up hope, when suddenly right at my feet, out flew a brownish long-l egged bird, a little larger than a crow. It was the bittern, of course. Uttering a couple of croaks, she flew down to the far end of the marsh where she dropped down into the tall grass.

My search was over, for when I spread the rushes apart, there on a mound of dead rushes were five khakicolored eggs. The nest was built in about a foot of water. In fact some of the eggs were wet on the under side. Less than three feet from the bittern's nest, a nest of Sora Rail was found containing twelve eggs. Taking a picture I departed from the area at once so as not to disturb her.

Mrs. Bittern had laid her eggs much sooner than I had anticipated for in no time at all the eggs were hatched. This I discovered on a beautiful sunday morning. I was wading closer to the nest very cautiously and, expecting the old girl to fly any second, when all of a sudden the most the most hideous and terrifying noise rent the air! It was a loud hissing with a sort of scream thrown in. My hair stood on end and I looked wildly in all directions, expecting to see a great Chinese dragon descending down upon me. Then I saw the bittern. There she was, standing on her nest, puffing herself up in the same manner as an owl, making her look three times as large. Her long neck was pulled back and her sharp mandibles opened so wide you could see right down her throat-- 
and out of that throat poured that awful rattle.

Three or four little ones were sitting around her and looked quite comical with their bills pointed sky ward trying their best to blend in with the scenery. As I drew closer, I expected her to fly, but no sir! she wasn't going to leave that nest.

At four feet I photographed her with the greatest of ease. This was nature photography handed to you on a platter. As I moved a foot closer, she flopped down over her young, even spreading her wings out to cover the ones at the edge of the nest. Nothing was going to harm her babies if she could help it.

After taking another picture or two, I decided to try for a really close-up -say 15 inches. A portrait attachment was put over the lens. When the camera was lowered to almost the desired distance, that long neck which was pulled tightly back against the

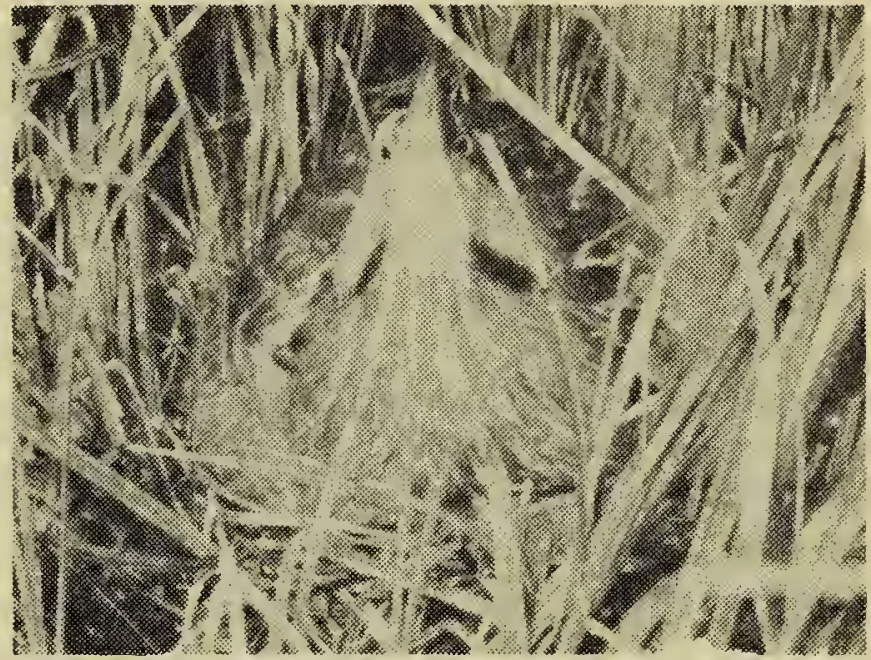

body, suddenly shot forward with the speed of light. Ping ! ! her sharp javalin-like bill struck the lens and sent it sailing several feet through the air where it fell into the water. I believe she struck at the camera lens because it resembled an eye. Needless to say, I didn't try for any more closeups,

Since then $I$ have met many bitterns but none with the courage and defiance of that one.

\title{
Birds and Bird Banding at Nipawin
}

\author{
By Maurice G. Street
}

I had a fairly good year at bird banding, despite a very cool, wet summer that does not make trapping birds very easy. However, I did give the thousand birds expected, a fairly close run: getting 932 of 54 species. Had a fair number of "returns" of birds banded in previous years as well as several distinct recoveries.

On September 28th I trapped a White - throated Sparrow that had been banded by Mrs. John A. Thompson, at Minneapolis, October 6th, 1949. This is the second foreign banded White-throat that I have captured. The first one, trapped October $3 / 46$, had been banded in Indiana the previous May. Incidently, White-throated $\mathrm{Sp}$ arrows are rarely recaptured, and their migration routes to and from their wintering grounds are still very much a puzzle.

Billy Matthews applied for and received a banding permit this past spring. Billy does his banding on the farm some $2^{1 / 2}$ miles south and east of Nipawin
Even having not received his supply bands until after spring migration had started, he did very well, trapping 492 birds of some 34 species. His banding station, bordering open fields, is reflected in his banding totals. Note his captures of Clay-colored and Savannah Sp arrow s.

This past summer a pair of Baltimore Orioles raised a family of five in a tall white poplar within sight of our kitchen window. After leaving the nest the young ones stayed aroung the house for several days. During this time one of the young found, by chance, the oatmeal porridge ( cooked thick ) I had placed under a drop-trap as bait for robins and catbirds and other ground feeders. Taking a liking to this food source, it stayed right on, even after the adults and other young had left the immediate vicinity. One morning I was surprised to notice that on the approach of the male robin, the young oriole crouched with quivering wings, and uttering its food call, accepted a worm 